\title{
RESEARCH PAPER \\ Seasonal and annual changes in the quality of native rangeland selected by grazing steers in northern Mexico
}

\author{
Osvaldo Reyes, Manuel Murillo, Esperanza Herrera, and Francisco O. \\ Carrete \\ Universidad Juárez del Estado de Durango, Facultad de Medicina Veterinaria y Zootecnia, Km 11.5 \\ Carretera Durango-Mezquital, Durango, 34320, Mexico.
}

\begin{abstract}
Osvaldo Reyes, Manuel Murillo, Esperanza Herrera, and Francisco O. Carrete. 2016. Seasonal and annual changes in the quality of native rangeland selected by grazing steers in northern Mexico. Cien. Inv. Agr. 43(2):203-212. The objective of this study was to determine and compare seasonally the chemical composition, in vitro gas production, in situ degradability and ruminal fermentation of the diet selected by cattle grazing on native rangeland over two years. Diet samples were collected from four esophageal fistulated steers $(350 \pm 3 \mathrm{~kg} \mathrm{BW})$, and four ruminally fistulated steers ( $342 \pm 1.5 \mathrm{~kg} \mathrm{BW})$ were used to evaluate degradation and ruminal fermentation. Data were analyzed using a repeated measurements design. The crude protein (CP), in vitro dry matter digestibility (IVDMD) and metabolizable energy (ME) were higher in $2008(\mathrm{P} \leq 0.01)$ and in the summer $(\mathrm{P} \leq 0.05)$. The volatile fatty acids (VFA) and propionate concentrations were affected by season and year $(\mathrm{P} \leq 0.05)$. The gas produced by the soluble (a) and insoluble (b) fractions and the constant rate of gas production (c) were greater in the summer and fall $(\mathrm{P} \leq 0.05)$. The values of effective degradability of dry matter $(E D D M)$ were greater in $2008(\mathrm{P} \leq 0.01)$ and during the summer $(\mathrm{P} \leq 0.05)$. Likewise, ruminal $\mathrm{NH}_{3} \mathrm{~N}$ concentrations were greater in 2008 and during the summer $(\mathrm{P} \leq 0.05)$. The total concentrations of volatile fatty acids (VFA) and propionate were affected by year $(\mathrm{P} \leq 0.05)$ and season $(\mathrm{P} \leq 0.05)$. This study showed a reduction in the nutritive value of the diet selected by grazing cattle due to annual and seasonal changes.
\end{abstract}

Key words: Cattle, grazing, in vitro gas production, in situ degradation, ruminal fermentation.

\section{Introduction}

Native rangelands are the main forage resource for beef cattle production in the arid and semiarid environments worldwide. However, the rangelands in these areas tend to vary greatly in quality and quantity. In these regions, the rangelands have

Received December 15, 2015. Accepted July 19, 2016. Corresponding author: reyesosvaldo@hotmail.com been gradually deteriorating due to droughts and overgrazing. Some studies report that, as a result of drastic climate change, the animals in the northern region of Mexico have periods of 90 to 100 days of favorable grazing conditions, and if the number of days is reduced, the survival of these animals may be in danger (Navarro et al., 2002). In general terms, the nutritional value of forage is the result of intrinsic plant factors such as the chemical composition, digestibility, and environmental factors, 
as well as the inherent factors of the animal and the interaction between the forages, the animals and the environment (Balseca et al., 2015; Morales et al., 2015). Under long-term drought conditions, the evaluation of the chemical composition of the diet of grazing cattle acquires relevance due to the seasonal variations in the nutrient content of the diet selected by the animals. The nutritional value of the diet is based mainly on intake, chemical composition and digestibility. However, with the establishment of new feeding ruminant evaluation systems, it is necessary to determine additional variables such as in situ degradability, in vitro gas production and ruminal fermentation patterns to increase the information regarding the nutritional value of the forages. Ruminal degradation and in vitro gas production have been regularly used to estimate the nutritive value of different classes of forages and to identify potential in the diet of ruminants (Babayemi, 2007; Silva et al., 2015). However, the study of the relationship between the quality of a diet and the ruminal environment in grazing cattle is largely unstudied with regard to livestock production. A more complete understanding of these relationships with climatic conditions (rainfall and temperature) across years and seasons will aid in the development of nutrition and grazing management programs that will improve the efficiency of livestock production in grazing beef cattle. We hypothesized that the chemical composition and patterns of degradation and ruminal fermentation of the diet selected by cattle on native rangelands varies annually and seasonally. Thus, the objective of this study was to determine the seasonal and year-to-year effects on the chemical composition, in vitro gas production, in situ degradation and ruminal fermentation of a native rangeland grazed by steers.

\section{Materials and methods}

\section{Study area and climatic conditions}

The study was carried out during two consecutive years (2007 and 2008) in a medium-sized shrub- grassland located east of the city of Durango, Mexico (24 $22^{\prime} \mathrm{N}, 104^{\circ} 32^{\prime} \mathrm{W}$ ), at an altitude of approximately $1938 \mathrm{~m}$, which has a dry temperate $\left(\mathrm{BS}_{1} \mathrm{k}\right)$ climate with average temperature and rainfall of $17.5^{\circ} \mathrm{C}$ and $450 \mathrm{~mm}$, respectively. Rainfall in 2007 and 2008 was 302.4 and 793.2 $\mathrm{mm}$, respectively. The study area covers 2,000 ha with an average forage biomass of $1,796 \mathrm{~kg}$ of $\mathrm{DM} \mathrm{ha}^{-1}$ and a stocking rate of 6 ha $\mathrm{AU}^{-1}$. During the two years of study, the vegetation cover was estimated by using minimum area sampling with nested points. Dominant grass species in the study site included Melinis repens (Willd.) (rose natal grass), Chloris virgata (feather fingergrass), Bouteloua gracilis (blue grama), Aristida adscensionis (sixweeks threeawn) and Andropogon barbinodis (cane bluestem). The main woody species in this landscape are Acacia tortuosa (poponax), Prosopis juliflora (mesquite), Opuntia spp (prickly pears and chollas), and Mimosa biuncifera (cat claw). The dominant herbaceous plants are Viguiera linearis (romerillo), Solanum elaeagnifolium (trompillo), Bidens aurea (aceitilla), Simsia amplexicaulis (acaualillo) and Thitonia tubaeformis (polocote).

\section{Animals and sample collection periods}

Diet samples were collected from four esophageal fistulated steers ( $350 \pm 3 \mathrm{~kg} \mathrm{BW})$, and four ruminally fistulated steers ( $342 \pm 1.5 \mathrm{~kg} \mathrm{BW}$ ) were used to evaluate degradation and ruminal fermentation. The steers were managed under continuous grazing during the entire study. After of an initial 23 day adaptation period, eight sampling periods of 11 day each were conducted: (1) January 2 to 12 , (2) February 4 to 14, (3) April 13 to 23, (4) May 15 to 25, (5) July 20 to 30, (6) August 11 to 21, (7) October 12 to 23 and (8) November 20 to 30. The first two collection periods were considered to be in winter; 3 and 4, spring; 5 and 6 , summer; and 7 and 8, fall. Surgery was performed on the steers according to procedures approved by the Animal Laboratory Care Advisory Committee of the Universidad Juárez del Estado de Durango, Mexico. 


\section{Chemical composition}

Diet samples were collected from the esophageal fistulated steers at 07:00 $\mathrm{h}$ during the first 4 days of each sampling period (Hakkila et al., 1987). Steers were fitted with screen wire bottom collection bags and allowed to graze for 30 to 45 min periods. Subsequently, samples $(300 \mathrm{mg}$ ) were pooled across a 4 day collection period for each animal. These samples were dried at $60{ }^{\circ} \mathrm{C}$ for $48 \mathrm{~h}$ and ground through a $1 \mathrm{~mm}$ screen in a Wiley mill. Dry matter (DM), organic matter (OM), crude protein (CP) (AOAC, 1997), neutral detergent fiber (NDF) (Van Soest et al., 1991) and in vitro dry matter digestibility (IVDMD) (ANKOM Technology, Macedon, New York, USA) were determined. We estimated ME content with the formulas used by Waterman et al. (2007).

\section{In vitro gas production}

The in vitro gas production was carried out using the gas production system (ANKOM Technology, Macedon, New York, USA) equipped with electronic transducers for gas production measurements. Esophageal samples $(300 \mathrm{mg})$ were placed in each module of incubation in triplicate. Buffer and mineral solutions were added according to Menke et al. (1979) in a 2:1 ratio to rumen liquid collected before the morning feeding from two rumen fistulated steers that had free access to Medicago sativa hay (Menke and Steingass, 1988). The collected ruminal liquid was maintained at 39 ${ }^{\circ} \mathrm{C}$ and was filtered through four layers of cheesecloth and flushed with $\mathrm{CO}_{2}$ gas. Sixty milliliters of this mixture were introduced in each module for incubation using ruminal liquid only as a blank. The gas volume was recorded at intervals of 0 , $3,6,9,15,24,36,48,72$ and $96 \mathrm{~h}$ of incubation. The cumulative gas data were fitted to the model proposed by McDonald (1981): $\mathrm{GP}_{(t)}=a+b\left(1-\mathrm{e}^{-c}\right.$ $\left.{ }^{(t-L)}\right)$; where: $\mathrm{GP}_{(t)}=$ gas produced at time $t ; a=$ gas produced by the soluble fraction; $b=$ gas produced by the insoluble but slowly fermenting fraction; $c=$ rate constant of gas production of fraction $b$; $t=$ time of fermentation; $L=$ lag time.

Ruminal fermentation, in situ degradability and passage rate

At 12:00 h on days 5 and 6 of the sampling period, ruminal liquid samples were extracted from the rumen fistulated steers. Approximately $100 \mathrm{~mL}$ of whole ruminal liquid was extracted from each steer, and the $\mathrm{pH}$ was measured immediately with a combination electrode. The collected ruminal liquid was strained through four layers of cheesecloth and divided into two subsamples. The first subsample $(10 \mathrm{~mL})$ was acidified with $0.3 \mathrm{~mL}$ of $50 \% \mathrm{H}_{2} \mathrm{SO}_{4}$, frozen immediately at $-40{ }^{\circ} \mathrm{C}$ and later analyzed for $\mathrm{NH}_{3} \mathrm{~N}$; the second subsample $(10 \mathrm{~mL})$ was acidified with $2.5 \mathrm{~mL}$ of $25 \%$ metaphosphoric acid and frozen at $-40{ }^{\circ} \mathrm{C}$ for later VFA analysis (Galyean, 1997).

On days 7, 8, 9 and 10 of the sampling period, the in situ degradability of the DM during grazing of ruminally fistulated steers was determined. Polyester bags $(10 \times 20 \mathrm{~cm}$; pore size of $50 \pm 10$ $\mu \mathrm{m}$; ANKOM, Spencerport, New York, USA) containing $10 \mathrm{~g}$ of sample ground to $2 \mathrm{~mm}$ were suspended in the rumen in duplicate for $0,3,6,9$, 15, 24, 36, 48, 72, and $96 \mathrm{~h}$. Bags were inserted into the rumen in reverse order of incubation times, and all bags were removed simultaneously at $0 \mathrm{~h}$, using an empty bag as a blank for correction. After removal, bags were rinsed in cold tap water until effluent was clear and then dried at $60^{\circ} \mathrm{C}$ for $48 \mathrm{~h}$ in a forced-air oven and weighed. The degradability of DM was determined at $\mathrm{t}(0)$ by immersing the bags containing $10 \mathrm{~g}$ of sample in the rumen for $1 \mathrm{~min}$ and then washing them as described above (Klopfenstein et al., 2001). The rumen degradation parameters of DM were calculated using the model of Orskov and Shand (1997): $\operatorname{Deg}_{(\mathrm{t})}=a+b$ $\left(1-\exp ^{-c t}\right)$, where $\operatorname{Deg}_{(\mathrm{t})}=$ disappearance of DM at time $t ; a=$ soluble fraction of the DM at the initiation of incubation (time 0 ), $b=$ fraction of DM degradable in the rumen, $c=$ constant rate of 
degradation of $b$, and $\mathrm{t}=$ time of incubation. On day 11 of the sampling period and before initiating grazing, we removed all ruminal content in each steer and placed them in black polyethylene bags, weighed them, removed $0.5 \mathrm{~kg}$ of the sample and immediately reintroduced the contents into the rumen of the steers from which they originated. Acid insoluble ash (AIA) was determined in the diet samples, as well as in the samples of ruminal content. The ruminal passage rate $(\mathrm{Kp})$ was determined by dividing the AIA content in the diet by the total AIA in the ruminal content (Ogden et $a l ., 2005)$. At once, the effective ruminal degradability of DM (EDDM) was calculated according to McDonald (1981): $\mathrm{ED}=a+b(c / c+k p)$, where $k p$ is the ruminal passage rate calculated in this study.

\section{Statistical analysis}

The normality of the data was revised using the Shapiro-Wilk test and then analyzed as a repeated measurements design using the MIXED procedure of SAS (2003). The model included effects for year and season and their interactions.
The sampling period was included as a repeated effect and animal within year $\times$ season was the subject for analysis. Autoregressive Order 1 was used as the covariance structure because it was a better fitting structure based on comparisons of covariance structures with Akaike and Bayesian information criteria (Littell et al., 1998). The curves of in situ degradability and in vitro gas production were adjusted using the NLIN procedure of SAS (2003).

\section{Results}

\section{Chemical composition}

No year $\times$ season interactions $(\mathrm{P}>0.05)$ were observed for CP, NDF, IVDMD and ME values. However, the CP, NDF, IVDMD and ME values were different between years ( $\mathrm{P} \leq 0.01$; Table 1$)$. The CP content increased by $184 \%$ in 2008 compared to 2007 , while the NDF content decreased $15.4 \%$ in 2008 compared to 2007 . These differences in the chemical composition of the diets may be induced by registered rainfall in both years of

Table 1. Chemical composition of the diet consumed by grazing steers.

\begin{tabular}{|c|c|c|c|c|}
\hline & $\begin{array}{c}\mathrm{CP} \\
\left(\mathrm{g} \mathrm{kg}^{-1} \mathrm{DM}\right)\end{array}$ & $\begin{array}{c}\mathrm{NDF} \\
\left(\mathrm{g} \mathrm{kg}^{-1} \mathrm{DM}\right)\end{array}$ & $\begin{array}{l}\text { IVDMD } \\
\left(\mathrm{g} \mathrm{kg}^{-1} \mathrm{DM}\right)\end{array}$ & $\begin{array}{c}\mathrm{ME} \\
\left(\mathrm{Mcal} \mathrm{kg}^{-1} \mathrm{DM}\right)\end{array}$ \\
\hline \multicolumn{5}{|l|}{ Year (Y) } \\
\hline 2007 & $45.3 b^{1}$ & $799.4 \mathrm{a}$ & $553.6 \mathrm{~b}$ & $0.910 \mathrm{~b}$ \\
\hline 2008 & $117.6 \mathrm{a}$ & $692.3 \mathrm{~b}$ & $701.4 \mathrm{a}$ & $2.3 \mathrm{a}$ \\
\hline SEM & 1.3 & 2.4 & 1.3 & 1.8 \\
\hline \multicolumn{5}{|l|}{ Season (S) } \\
\hline Spring & $44.2 \mathrm{~d}$ & $800.3 \mathrm{a}$ & $551.4 \mathrm{c}$ & $0.902 \mathrm{~b}$ \\
\hline Summer & $119.2 \mathrm{a}$ & $671.3 \mathrm{~d}$ & $710.3 \mathrm{a}$ & $2.4 \mathrm{a}$ \\
\hline Fall & $106.3 \mathrm{~b}$ & $693.0 \mathrm{~b}$ & $608.6 \mathrm{~b}$ & $2.2 \mathrm{a}$ \\
\hline Winter & $52.6 \mathrm{c}$ & $762.7 \mathrm{c}$ & $554.7 \mathrm{c}$ & $1.0 \mathrm{~b}$ \\
\hline SEM & 1.8 & 1.1 & 1.3 & 1.2 \\
\hline \multicolumn{5}{|l|}{ Effects } \\
\hline $\mathrm{Y}$ & $* *$ & $* *$ & $* *$ & $* *$ \\
\hline S & * & $*$ & $*$ & $*$ \\
\hline $\mathrm{Y} * \mathrm{~S}$ & NS & NS & NS & NS \\
\hline
\end{tabular}

${ }^{1}$ Means with different letters within the same column are different $*(\mathrm{P} \leq 0.05) ; * *(\mathrm{P} \leq 0.01)$.

SEM: Standard error of mean.

NS: non-significant. 
the study. The CP, IVDMD and ME values were greater in summer and fall compared to winter and spring $(\mathrm{P} \leq 0.05)$; while NDF content was higher in spring and winter compared to summer and fall $(\mathrm{P} \leq 0.05)$.

\section{In vitro gas production}

The parameters of in vitro gas production are shown in Table 2 . No year $\times$ season interactions were observed for the parameters of in vitro gas production $(\mathrm{P}>0.05)$. The values of "a", "b" and "c" were 106, 30.8, and 188\% higher, respectively, in 2008 compared to 2007 ( $\mathrm{P} \leq 0.05)$. Nevertheless, the values of the lag time were greater in 2007 than in $2008(\mathrm{P} \leq 0.05)$. The gas produced by the soluble fraction (a) and by the insoluble but slowly fermentable fraction (b) were greater in summer and fall compared with winter and spring $(\mathrm{P} \leq 0.05)$. The highest gas production rate was obtained in summer $\left(5.4 \mathrm{~mL} \mathrm{~h}^{-1}\right)$ and the lowest in spring (1.6 $\left.\mathrm{h}^{-1}\right)(\mathrm{P} \leq 0.05)$. The duration of lag time (L) was highest in spring and the lowest in summer $(\mathrm{P} \leq 0.05)$.

\section{In situ ruminal degradability of dry matter}

The parameters of in situ degradability and effective degradability of dry matter (EDDM) are shown in Table 3 . No year $\times$ season interactions $(\mathrm{P}>0.05)$ were observed for "a", "b", "c" or "EDDM". The values of $a, b, c$, and EDDM were greater in 2008 versus $2007(\mathrm{P} \leq 0.01)$. The "a", "b", "c", and EDDM values were affected by season of the year $(\mathrm{P} \leq 0.05)$. Additionally, these values were higher during summer and fall $(\mathrm{P} \leq 0.05)$.

\section{Ruminal fermentation}

The ruminal fermentation patterns are shown in Table 4. Interactions were detected for year $\times$ season $(\mathrm{P} \leq 0.05)$. The $\mathrm{pH}$ value was lowest in summer compared with fall, winter and spring $(\mathrm{P} \leq 0.05)$. The ruminal $\mathrm{NH}_{3} \mathrm{~N}$ concentration was greater in 2008 compared with $2007(\mathrm{P} \leq 0.05)$, while the $\mathrm{NH}_{3} \mathrm{~N}$ concentration was higher in summer and fall $(\mathrm{P} \leq 0.05)$.

Table 2. In vitro gas production of the diet consumed by grazing steers.

\begin{tabular}{|c|c|c|c|c|}
\hline & $\begin{array}{c}\mathrm{a} \\
\left(\mathrm{mL} 200 \mathrm{mg}^{-1} \mathrm{DM}\right)\end{array}$ & $\begin{array}{c}\mathrm{b} \\
\left(\mathrm{mL} 200 \mathrm{mg}^{-1} \mathrm{DM}\right)\end{array}$ & $\begin{array}{c}c \\
\left(\mathrm{~mL} \mathrm{~h}^{-1}\right)\end{array}$ & $\begin{array}{c}\mathrm{L} \\
(\mathrm{h})\end{array}$ \\
\hline \multicolumn{5}{|l|}{ Year (Y) } \\
\hline 2007 & $3.3 b^{1}$ & $74.3 \mathrm{~b}$ & $1.8 \mathrm{~b}$ & $4.6 \mathrm{~b}$ \\
\hline 2008 & $6.8 \mathrm{a}$ & $97.2 \mathrm{a}$ & $5.2 \mathrm{a}$ & $1.2 \mathrm{~b}$ \\
\hline SEM & 1.8 & 2.1 & 1.1 & 2.4 \\
\hline \multicolumn{5}{|l|}{ Season (S) } \\
\hline Spring & $2.1 \mathrm{c}$ & $71.2 \mathrm{~d}$ & $1.6 \mathrm{~d}$ & $4.8 \mathrm{a}$ \\
\hline Summer & $6.6 \mathrm{a}$ & $98.5 \mathrm{a}$ & $5.4 \mathrm{a}$ & $1.2 \mathrm{c}$ \\
\hline Fall & $3.9 \mathrm{~b}$ & $83.6 \mathrm{~b}$ & $2.9 \mathrm{~b}$ & $3.3 \mathrm{~b}$ \\
\hline Winter & $3.7 \mathrm{~b}$ & $77.2 \mathrm{c}$ & $2.3 \mathrm{c}$ & $3.7 \mathrm{~b}$ \\
\hline SEM & 1.6 & 1.2 & 2.7 & 2.2 \\
\hline \multicolumn{5}{|l|}{ Effects } \\
\hline $\mathrm{Y}$ & $*$ & $*$ & * & $*$ \\
\hline S & $*$ & $*$ & * & $*$ \\
\hline $\mathrm{Y}^{*} \mathrm{~S}$ & NS & NS & NS & NS \\
\hline
\end{tabular}

${ }^{1}$ Means with different letters within column are different $*(\mathrm{P} \leq 0.05)$.

$\mathrm{a}=$ gas produced by the soluble fraction; $\mathrm{b}=$ gas produced by the insoluble but slowly fermenting fraction; $\mathrm{c}=$ rate constant of gas production of fraction $b ; t=$ time of fermentation; $L=$ lag time.

SEM: Standard error of mean.

NS: non-significant. 
Table 3. In situ degradability and effective degradability of dry matter of the diet consumed by grazing steers.

\begin{tabular}{|c|c|c|c|c|}
\hline & $\begin{array}{c}\mathrm{a} \\
\left(\mathrm{g} \mathrm{kg}^{-1} \mathrm{DM}\right)\end{array}$ & $\begin{array}{c}\mathrm{b} \\
\left(\mathrm{g} \mathrm{kg}^{-1} \mathrm{DM}\right)\end{array}$ & $\begin{array}{c}\mathrm{c} \\
\left(\mathrm{h}^{-1}\right)\end{array}$ & $\begin{array}{c}\text { EDDM } \\
\left(\mathrm{g} \mathrm{kg}^{-1} \mathrm{DM}\right)\end{array}$ \\
\hline \multicolumn{5}{|l|}{ Year $(\mathrm{Y})$} \\
\hline 2007 & $102.6 b^{1}$ & $512.4 \mathrm{~b}$ & $0.021 \mathrm{~b}$ & $501.7 \mathrm{~b}$ \\
\hline 2008 & $286.7 \mathrm{a}$ & $726.3 \mathrm{a}$ & $0.055 \mathrm{a}$ & $697.8 \mathrm{a}$ \\
\hline SEM & 2.3 & 2.1 & 0.022 & 2.8 \\
\hline \multicolumn{5}{|l|}{ Season (S) } \\
\hline Spring & $99.8 \mathrm{~d}$ & $510.3 \mathrm{~d}$ & $0.020 \mathrm{~d}$ & $496.4 \mathrm{~d}$ \\
\hline Summer & $279.3 \mathrm{a}$ & $715.9 \mathrm{a}$ & $0.061 \mathrm{a}$ & $671.6 \mathrm{a}$ \\
\hline Fall & $220.7 \mathrm{~b}$ & $706.8 \mathrm{~b}$ & $0.053 \mathrm{~b}$ & $612.6 \mathrm{~b}$ \\
\hline Winter & $184.1 \mathrm{c}$ & $529.4 \mathrm{c}$ & $0.028 \mathrm{c}$ & $587.4 \mathrm{c}$ \\
\hline SEM & 2.8 . & 1.2 & 0.012 & 1.6 \\
\hline \multicolumn{5}{|l|}{ Effects } \\
\hline $\mathrm{Y}$ & $* *$ & $* *$ & $* *$ & $* *$ \\
\hline S & * & * & $*$ & $*$ \\
\hline $\mathrm{Y} * \mathrm{~S}$ & NS & NS & NS & NS \\
\hline
\end{tabular}

${ }^{1}$ Means with different letters within the same column are different $* *(\mathrm{P} \leq 0.01) ; *(\mathrm{P} \leq 0.05) ; a \mathrm{a}=$ soluble fraction of the $\mathrm{DM}$ at the initiation of incubation (time 0$), b=$ fraction of DM degradable in the rumen, $c=$ constant rate of degradation of $b$. EDDM was estimated with the following passage rate obtained in this study: winter $\left(0.017 \mathrm{~h}^{-1}\right)$; spring $\left(0.022 \mathrm{~h}^{-1}\right)$; summer $\left(0.030 \mathrm{~h}^{-1}\right)$; fall $\left(0.024 \mathrm{~h}^{-1}\right)$.

SEM: Standard error of mean.

NS: non-significant.

Table 4. Ruminal fermentation patterns of the diet consumed by grazing steers.

\begin{tabular}{|c|c|c|c|c|c|c|}
\hline & \multirow[b]{2}{*}{$\mathrm{pH}$} & \multirow{2}{*}{$\begin{array}{c}\mathrm{NH}_{3} \mathrm{~N} \\
\left(\mathrm{mg} \mathrm{dL}^{-1}\right)\end{array}$} & \multirow{2}{*}{$\begin{array}{l}\text { VFA } \\
(\mathrm{mM})\end{array}$} & Acetate & Propionate & Butyrate \\
\hline & & & & \multicolumn{3}{|c|}{$\mathrm{mol} 100 \mathrm{~mol}^{-1}$} \\
\hline \multicolumn{7}{|l|}{ Year (Y) } \\
\hline 2007 & $6.8 \mathrm{a}^{1}$ & $4.8 \mathrm{~b}$ & $88.3 \mathrm{~b}$ & $69.7 \mathrm{a}$ & $10.7 \mathrm{~b}$ & $8.1 \mathrm{a}$ \\
\hline 2008 & $6.5 \mathrm{a}$ & $12.7 \mathrm{a}$ & $101.1 \mathrm{a}$ & $61.8 \mathrm{~b}$ & $18.3 \mathrm{a}$ & $5.3 \mathrm{~b}$ \\
\hline SEM & 0.10 & 0.48 & 1.6 & 1.1 & 2.2 & 1.4 \\
\hline \multicolumn{7}{|l|}{ Season (S) } \\
\hline Spring & $6.7 \mathrm{a}$ & $4.2 \mathrm{~b}$ & $85.2 \mathrm{c}$ & $68.5 \mathrm{a}$ & $9.8 \mathrm{~d}$ & $8.4 \mathrm{a}$ \\
\hline Summer & $6.4 \mathrm{~b}$ & $12.8 \mathrm{a}$ & $103.3 \mathrm{a}$ & $60.7 \mathrm{c}$ & $19.8 \mathrm{a}$ & $4.2 \mathrm{c}$ \\
\hline Fall & $6.6 \mathrm{a}$ & $10.3 \mathrm{a}$ & $91.1 \mathrm{~b}$ & $66.4 \mathrm{~b}$ & $14.6 \mathrm{~b}$ & $7.6 \mathrm{~b}$ \\
\hline Winter & $6.8 \mathrm{a}$ & $4.8 \mathrm{~b}$ & $87.2 \mathrm{c}$ & $68.3 \mathrm{a}$ & $11.5 \mathrm{c}$ & $8.5 \mathrm{a}$ \\
\hline SEM & 0.14 & 0.91 & 2.6 & 1.4 & 2.0 & 2.7 \\
\hline Effects & $\mathrm{P} \leq$ & $\mathrm{P} \leq$ & $\mathrm{P} \leq$ & $\mathrm{P} \leq$ & $\mathrm{P} \leq$ & $\mathrm{P} \leq$ \\
\hline $\mathrm{Y}$ & * & * & * & * & $*$ & * \\
\hline S & $*$ & $*$ & $*$ & * & $*$ & $*$ \\
\hline $\mathrm{Y} * \mathrm{~S}$ & $*$ & $*$ & $*$ & $*$ & $*$ & $*$ \\
\hline
\end{tabular}

${ }^{1}$ Means with different letters within the same column are different $*(\mathrm{P} \leq 0.05)$.

SEM: Standard error of mean.

NS: non-significant. 
On the other hand, the total VFA concentration was affected by year $(\mathrm{P} \leq 0.05)$ and season $(\mathrm{P} \leq 0.05)$. The VFA concentrations were lower in spring and winter and higher in summer and fall $(\mathrm{P} \leq 0.05)$. The acetate concentration was higher in 2007 than $2008(\mathrm{P} \leq 0.05)$. Acetate concentrations did not differ between spring, fall and winter $(\mathrm{P}>0.05)$, although the lowest concentration was observed during summer $(\mathrm{P} \leq 0.05)$. The propionate concentration was affected by year $(\mathrm{P} \leq 0.05)$ and season $(\mathrm{P} \leq 0.05)$, with the highest values in 2008 and summer and the lowest in 2007 and other seasons of year. The butyrate concentration was higher in 2007 than 2008 ( $\mathrm{P} \leq 0.05)$. The butyrate concentration was lowest during summer compared with the other seasons of the year $(\mathrm{P} \leq 0.01)$.

\section{Discussion}

According to NRC (2000), CP minimum content of $80 \mathrm{~g} \mathrm{~kg}^{-1}$ in forage is adequate for grazing cattle. Therefore, native rangeland may supply enough CP for grazing cattle, except for during the spring and winter. The value of ME registered in the winter and spring (0.902, 1.0 Mcal $\mathrm{kg}^{-1} \mathrm{DM}$, respectively) indicate that the energy requirements for the maintenance of grazing cattle (2.0 Mcal kg-1 DM; NRC, 2000) cannot be satisfied. Hakkila et al. (1987) reported that the chemical composition of the diet of grazing cattle is higher in the summer and fall versus the winter and spring, and they attributed the differences to the phenology of rangeland plants.

There is very little information about the in vitro gas production of the diets selected by range beef cattle. However, the in vitro gas production parameters found in the present study are similar to those reported in browse trees (Babeyemi, 2007). Likewise, the differences between year and season in the values of "a", "b" and "c" may be attributed to the concentration of soluble carbohydrates in the diet selected by grazing cattle (Reyes et al.,
2012). The variations observed between years and seasons in the lag time may be explained by the neutral detergent fiber and lignin contents of the diet consumed by grazing cattle, which delay the onset of degradation of the nutrients in the rumen (Fievez et al., 2005).

Under similar conditions to this study, Reyes et al. (2006) found differences between seasons in "a", "b" and "c" values of consumed diet by grazing cattle. Seasonal differences in the parameters of in situ degradability of DM may be attributed to protein, fiber and lignin contents of the diet selected by study animals (Guerrero et al., 2010). Ramírez et al. (2004) suggested that weather conditions are the cause of these differences because temperature decreases and rainfall increases the degradability of dry matter in the grasslands of northern Mexico.

These results are largely consistent with those found by Gunter et al. (1995) in grazing cattle on desert rangelands. The ruminal $\mathrm{NH}_{3} \mathrm{~N}$ concentrations of steers were greater than $5 \mathrm{mg} \mathrm{dl}^{-1}$, the concentration suggested for microbial growth, and more than the 1 to $2 \mathrm{mg} \mathrm{dl}^{-1}$ concentration proposed by Petersen (1987) as necessary for optimal fiber degradation.

Adams et al. (1987) stated that VFA concentrations decrease with advancing the growing season. Acetate is considered to be reflective of cell wall fermentation, and increased acetate levels are normally associated with declining forage quality (Van Soest, 1994). Propionate concentration is associated with soluble carbohydrate ruminal fermentation during periods of active rangeland growth (McCollum et al., 1985). Similar results to this study with respect to the ruminal fermentation patterns in grazing cattle were reported by Choat et al. (2003).

This study shows a reduction in the nutritive value of the diet due to annual and seasonal changes. 
These changes are accompanied by decreases in the in vitro gas production parameters, as well as the degradation and ruminal fermentation of the diet of grazing cattle. The protein and energy supplementation might be beneficial for cattle grazing during spring and winter. Our study provides new knowledge that can be used to help improve the precisions of the formulation of supplements that grazing cattle need to improve their productive and reproductive performance.

\section{Resumen}

Osvaldo Reyes, Manuel Murillo, Esperanza Herrera, y Francisco O. Carrete. 2016. Cambios estacionales y anuales en la calidad de la dieta seleccionada por novillos en pastoreo en un pastizal nativo del norte de México. Cien. Inv. Agr. 43(2):203-212. El objetivo de este estudio fue determinar y comparar las estaciones durante dos años la composición química, producción de gas in vitro, degradabilidad in situ y fermentación ruminal de la dieta seleccionada por ganado en un pastizal nativo. Muestras de la dieta fueron colectadas con cuatro novillos fistulados del esófago (350 $\pm 3 \mathrm{~kg}$ PV), cuyos novillos $(342 \pm 1.5 \mathrm{~kg}$ PV) fueron usados para evaluar la degradación y fermentación ruminal. Los datos fueron analizados con un diseño de mediciones repetidas. La proteína cruda (PC), digestibilidad in vitro de la materia seca (DIVMS) y energía metabolizable (EM) fueron mayores en $2008(\mathrm{P} \leq 0.05)$ y en el verano $(\mathrm{P} \leq 0.05)$. Los ácidos grasos volátiles $(\mathrm{AGV})$ y las concentraciones de propionato se vieron afectados por la temporada y el año $(\mathrm{P} \leq 0.05)$. Las fracciones soluble (a) e insoluble (b) y la tasa constante de degradación (c) de la producción de gas fueron mayores en verano y otoño $(\mathrm{P} \leq 0.05)$. Los valores de degradabilidad efectiva de la materia seca (DEMS) fueron mayores en $2008(\mathrm{P} \leq 0.01)$ y veranos $(\mathrm{P} \leq 0.05)$. Igualmente, las concentraciones de $\mathrm{NNH}_{3}$ fueron mayores en 2008 y el verano $(\mathrm{P} \leq 0.05)$. La concentración total de ácidos grasos volátiles $(\mathrm{AGV})$ y propionato fueron afectados por los años $(\mathrm{P} \leq 0.05)$ y estaciones del año $(\mathrm{P} \leq 0.05)$. En este estudio se observó una reducción en el valor nutritivo de la dieta seleccionada por ganado en pastoreo debido a cambios estacionales y anuales.

Palabras clave: Degradabilidad in situ, fermentación ruminal, ganado, pastoreo, producción de gas in vitro.

\section{References}

Adams, D.C., R.C. Cochran, and P.Q. Currier. 1987. Forage maturity effects on rumen fermentation, fluid flow, and intake in grazing steers. J. Range Manage 40:404-408.

AOAC. 1997. Official Methods of Analysis. Association of Official Analytic Chemists, Washington, D.C. USA.

Babayemi, O.J. 2007. In vitro fermentation characteristics and acceptability by West African dwarf goats of some dry season forages. Afr. J. Biotechnol. 6:1260-1265.
Balseca, D.G., E.G. Cienfuegos, H.B. López, H.P. Guevara, and J.C. Martínez. 2015. Nutritional value of Brachiarias and forage legumes in the humid tropics of Ecuador. Cien. Inv. Agr. 42(1):57-63.

Choat, W.T., C.R. Krehbiel, G.C. Duff, R.E. Kirksey, L.M. Lauriault, J.D. Rivera, B.M. Capitan, D.A. Walker, G.B. Donart, and C.L. Goad. 2003. Influence of grazing dormant native range or winter pasture on subsequent finishing cattle performance, carcass characteristics and ruminal metabolism. J. Anim. Sci. 81:31913201 . 
Fievez, V., O.J. Babayemi, and D. Demeyer. 2005. Estimation of direct and indirect gas production in syringes: A tool to estimate short chain fatty acid production that requires minimal laboratory facilities. Anim. Feed Sci. Technol. 123124:197-210.

Galyean, M. L. 1997. Laboratory Procedures in Animal Nutrition Research. Texas Tech University. 77 pp. Available online at: www.app.depts.ttu. edu (Website accessed February 17, 2007).

Guerrero, C.M., A.S. Juarez, R.G. Ramirez, R. Montoya, M. Murillo, O. La, and M.A. Cerrillo. 2010. Chemical composition and protein degradability of native forages of the semiarid region of northerm Mexico. Cuban J. Agric. Sci. 44:143-149.

Gunter, S.A., F.T. McCollum, R.L. Gillen, and L.J. Krysl. 1995. Diet quality and ruminal digestion in beef cattle grazing midgrass prairie rangeland or plains bluestem pasture throughout the summer. J. Anim. Sci. 73:1174-1186.

Hakkila, M.D., J.L. Holechek, J.D. Wallace, D.M. Anderson, and M. Cardenas. 1987. Diet and forage intake of cattle on desert grassland range. J. Range Manage 40:339-342.

Klopfenstein, T.J., R.A. Mass, K.W. Creighten, and H.H. Patterson. 2001. Estimating forage protein degradation in the rumen. J. Anim. Sci. 79(1):E217.

Littell, R.C., P.R. Henry, and C.B. Ammerman. 1998. Statistical analysis of repeated measures data using SAS procedures. J. Anim. Sci. 76:1216-1231.

McCollum, F.T., M.L. Galyean, L.J. Krysl, and J.D. Wallace. 1985. Cattle grazing blue grama rangeland. I. Seasonal diets and rumen fermentation. J. Range Manage 38:539-542.

McDonald, J. 1981. A revised model for the estimation of protein degradability in the rumen. $\mathrm{J}$. Agri. Sci. 96:251-252.

Menke, K.H., and H. Steingass. 1988. Estimation of the energetic feed value obtained from chemical analysis and in vitro gas production using rumen fluid. Animal Research and Development 28:7-55.

Menke, K.H., L. Raab, A. Salewski, H. Steingass, D. Fritz and W. Schmeider. 1979. The estimation of the digestibility and metabolizable energy content of ruminant feeding-stuffs from the gas pro- duction when they are incubated with rumen liquor in vitro. J. Agric. Sci. (Camb.) 93:217-222.

Morales, R., J. Parga, I. Subiabre, and Realini. 2015. Finishing strategies for steers based on pasture or silage plus grain and time and feed and their effects on beef quality. Cien. Inv. Agr. 42:5-18.

Navarro, J.M., D. Galt, J. Holechek, J. McCormick, and F. Molinar. 2002. Long-term impacts of livestock grazing on Chihuahua Desert rangelands. J. Range Manage 55:400-405.

NRC. 2000. Nutrient Requirements of Beef Cattle. Seventh ed. National Academic Press. Washington D.C. 246 pp.

Ogden, R.K., W.K. Coblentz, K.P. Coffey, J.E. Turner, D.A. Scarbrough, J.A. Jennings, and M.D. Richardson. 2005. Ruminal in situ disappearance kinetics of dry matter and fiber in growing steers for common crabgrass forages sampled on seven dates in northern Arkansas. J. Anim. Sci. 83:1142-1152.

Orskov, E.R. and W.J. Shand. 1997. Use of the nylon bag technique for protein and energy evaluation and for rumen environment studies in ruminants. Livestock Research for Rural Development 9:1-10.

Petersen, M.K. 1987. Nitrogen supplementation of grazing livestock. Proceedings Grazing Livestock. University of Wyoming. March 22-23. Indiana, U.S.A. p. 115-122.

Ramírez, R.G., G.F.W. Haenlein, G.C. García-Castillo, and M.A. Núñez-González. 2004. Protein, lignin and mineral contents and in situ dry matter digestibility of native Mexican grasses consumed by range goats. Small Rum. Res. 52:261-269.

Reyes, E.O., M. Murillo, E. Herrera, E. Gutiérrez, A.S. Juárez, and A. Cerrillo. 2012. Influence of the season on nutritional and metabolic indicators of grazing cattle in North of Mexico. Cuban J. Agric. Sci. 4:375-380.

Reyes, E.O., M. Murillo, E. Herrera, M. Guerrero, G. Nevarez, R. Montoya, M.A. Cerrillo, and A.S. Juárez. 2006. In situ dry matter degradation kinetics of the diet selected by grazing cattle in a grassland of Northern Mexico. Annual Meeting, American Dairy Science Association -American Society of Animal Science, Minneapolis, U.S.A. p. 1-742. 
SAS, 2003. User's Guide: Statistics (Release 9.1). SAS. Institute, Cary, North Caroline, U.S.A.

Silva, A.M. de A., S.V. Alves, L.R. Bezerra, H. Carneiro, R.L. Oliveira, F.F. de Medeiros, J.M. Pereira Filho, and D.R.C. de Araujo. 2015. Potential in vitro degradability and gas production of the byproducts of the biodiesel chain. Cien. Inv. Agr. 42:285-293.

Van Soest, P.J. 1994. Nutritional Ecology of the Ruminant. 2th Ed. New York, Cornell Univesity Press. U.S.A.
Van Soest, P.J., J. B. Robertson, and B.A. Lewis. 1991. Methods for dietary fiber, neutral detergent fiber, and non-starch polysaccharides in relation to animal nutrition. J. Dairy Sci. 74:3583-3597.

Waterman, R.C., E.E. Grings, T.W. Geary, A.J. Roberts, L.J. Alexander, and M.D. MacNeil. 2007. Influence of seasonal forage quality on glucose kinetics of young beef cows. J. Anim. Sci. 85:2582-2595. 